\title{
Legal Protection Againts Violations of Human Rights That Abuse Uighur Ethnic Women in China
}

\author{
Endah Rantau Intisari', Dewa Gede Sudika Mangku² \\ ${ }^{1}$ Fakulty of Law, Tanjungpura University, Pontianak - Indonesia \\ ${ }^{2}$ Fakulty of Law and Social Science, Universitas Pendidikan Ganesha, Indonesia \\ Email: ${ }^{1}$ endah.rantau.itasari@hukum.untan.ac.id , ${ }^{2}$ sudika.mangku@undiksha.ac.id

\begin{tabular}{llll}
\hline Submitted & $:$ December, $29^{\text {th }}, 2020$ & Revision & $:$ May, $28^{\text {th }}, 2021$ \\
Reviewed & $:$ April, $11^{\text {th }}, 2021$ & Published & $:$ June, $18^{\text {th }}, 2021$
\end{tabular}

\begin{abstract}
The purpose of this research is to respect the legal protection of ethnic Uighur women in Xinjiang, China from the perspective of International Human Rights and to find out and study the resolution of cases of serious international human rights violations against ethnic Uighur women in Xinjiang, China. Legal protection for women of Uighur ethnicity is based on articles 3,4,5,9,10,11, the Universal Declaration of Human Rights, namely by providing protection in the form of protection of the right to life, the rights to freedom, and the right to personal security, and others that are regulated in international legal instruments. 2) Serious human rights violations committed by the government of Xinjiang, China are not justified by international law because they violate the provisions stipulated in the subsequent Universal Declaration of Human Rights for the incidents of human rights violations, so the settlement of disputes between the two parties is carried out by negotiation or mediation. If this method is not effective, the UN Security Council can submit the case to an international court such as the International Criminal Court as regulated in article 1 of the 1998 Rome Statute.
\end{abstract}

Keywords: legal protection, human rights, uighur

Abstrak: Tujuan dari penelitian ini ialah berkenaan tentang perlindungan hukum terhadap perempuan etnis Uighur di Xinjiang, China dalam perspektif Hak Asasi Manusia Internasional serta untuk mengetahui dan mengkaji penyelesaian kasus pelanggaran Hak Asasi Manusia Internasional berat terhadap kaum perempuan etnis Uighur di Xinjiang, China. Perlindungan Hukum terhadap perempuan etnis uighur berdasarkan pada pasal 3,4,5,9,10,11, Deklrasi Universal Hak Asasi Manusia yakni dengan memberikan perlindungan dalam bentuk perlindungan hak untuk hidup, 
hak- hak atas kebebasan, dan hak atas keamanan diri, dan lainnya yang di atur di dalam instrument - instrument hukum intenasional. 2) pelanggaran HAM Berat yang dilakukan oleh pemerintah Xinjiang, China tidak di benarkan oleh hukum internasional karena melanggar ketentuan yang diatur dalam Deklarasi Universal HAM selanjutnya atas insiden pelanggaran HAM tersebut, maka penyelesaian sengketa yang dilakukan antar kedua belah pihak dilakukan dengan cara negosiasi atau mediasi terlebih dahulu. Apabila cara tersebut kurang efektif maka Dewan Keamanan PBB dapat mengajukan kasus tersebut ke peradilan internasional seperti Pengadilan Pidana Internasional (International Criminal Court ) yang di atur di dalam pasal 1 Statuta Roma Tahun 1998

Kata Kunci: perlindungan hukum, hak asasi manusia, uighur

\section{Introduction}

Humans as creatures of the Almighty God who have the task of managing and maintaining the universe with full devotion and full responsibility for the welfare of mankind, are granted by the creator human rights to ensure the existence of dignity and dignity of his own dignity and the harmony of his environment. As part of the dignity, human rights are basic rights inherent naturally in humans, are universal and permanent, therefore they must be protected, respected, defended, and should not be ignored, diminished, or taken away by anyone. Apart from human rights, human beings also have basic obligations between one human being against another and towards society as a whole in the life of society, nation and state.

International law, especially after World War I, has given individuals status as independent international legal subjects in the international legal system. Individuals in international human rights law can also defend their rights directly, which initially apply to the European community in the European Convention and apply in the American Convention. The bitter and bitter experiences of mankind from world wars that have occurred twice, where the dignity of human rights is trampled on, there has been a growing awareness of mankind to place respect and respect for human rights into the UN Charter which as its realization emerged later. The Universal Declaration of Human Rights, which was accepted by acclamation by the General Assembly of the UN General Assembly on 10 December 1948.

The state is the main, important legal subject and has the greatest authority as a subject of international law. Article 1 of the Montevideo Convention of 1933 concerning the Rights and Duties of the State as an international subject, states that the main conditions in the establishment of an independent and sovereign State are, 
with the territory of a State, the existence of clear State boundaries, the existence of residents as supporters in the course of a wheels of government, and the existence of a legal government so that the State has the ability to carry out or establish relations with various other international legal subjects.

Article 1 of the Montevideo Convention states that there are 3 main conditions, namely: the existence of a state territory with clear territorial boundaries, the existence of a population to support the running of a government, the existence of a legitimate government, and it has been recognized since the 19th century in Europe., and what is known as an additional requirement is the fourth condition, namely, the ability to carry out or establish relations with various international legal subjects. The criteria for granting recognition to a new State are based on or guided by several things, namely: belief in the existence of stability in that country, general support from the people or people of the country concerned, willingness to carry out international obligations.

The state as a subject of international law is a party that certainly has the obligation to protect, guarantee and fulfill human rights. State obligations related to human rights internationally are regulated in various international human rights law instruments, namely: Universal Declaration Of Human Rights, hereinafter abbreviated as UDHR, International Covenant On Civil And Political Rights hereinafter abbreviated as ICCPR, The International Covenant On Economic, Social And Cultural Rights, hereinafter abbreviated as ICESCR. Article 2 of the Universal Declaration of Human Rights (UDHR) of 1948 states that the law or international position of the country or region where a person comes from, whether from an independent state, is in the form of guardianship, colony or that is under the boundaries of sovereignty (Lasmawan, 2020).

It is affirmed by the statement in UDHR 1948 that everyone has the right to life, the right to freedom and safety as an individual. Furthermore, there will be no difference on the basis of political position. Human rights in practice or implementation are regulated in international law. Several international legal experts provide various definitions of human rights, including the following: Life becomes full of dignity if the majority of people understand and understand human rights which are basic or fundamental rights (Munthe, M. 2016).

Mahfud MD states that human rights are a right that exists and is inherent in the dignity of every human being that has been brought from the moment humans were born into the world and this right has a natural character. Article 1 of Law of 
the Republic of Indonesia Number 39 of 1999 concerning Human Rights explains that human rights are a set of rights inherent in the nature and existence of every human being as a creature of God and is a gift given by God which of course must be respected, upheld, and protected by the law of the government of the State, as well as every person for the sake of the honor of protection of human dignity. In article 3 of Law Number 39 Year 1999 concerning Human Rights, it contains discrimination. Discrimination is a limitation, harassment or exclusion carried out directly or indirectly on the basis of human differentiation on the basis of religion, ethnicity, race, ethnicity, group, class, social status, economic status, gender, language and political beliefs, which can resulting in the reduction, deviation or elimination of the recognition, implementation or use of human rights and basic freedoms in life, both individually and collectively, especially in the political, economic, legal, social and other aspects of life. Thus, factors such as race, gender, religion, and language cannot confirm the embodiment or existence of human rights in humans themselves (Andrey, 2016). The Uighurs are one of the official ethnic minorities in the Republic.

The Chinese people (PRC), where Uighur ethnic women themselves are descended from ancient tribes that have spread across Central Asia. The Uighur ethnic community has experienced various forms of human rights violations to date, the forms of human rights violations received by ethnic Uighur women in the form of torture and coercion to no longer embrace Islam and they are exiled and even shot to death, which is ultimately for the actions that have been committed by the Xinjiang government caused many victims both children and adults. Based on this description, the researcher found problems, namely: Based on the problem boundaries described above, the author raises the problem, namely Legal Protection Against Human Rights Violations That Befall Uighur Muslim Ethnic Women in China.

Normative legal research is a type of legal research used in this study. Normative legal research rests on a method that focuses on library law research using library materials, as well as laws and regulations. This type of legal research uses the type of normative research which systematically studies and analyzes the protection of the law against human rights violations that befall Uighur Muslim ethnic women in China.

In this legal research, an approach based on statutory regulations (Statute Approach) is used, and a conceptual approach (Conceptual Approach). The Statute Approach is an approach using laws and regulations relating to legal issues that will 
be discussed in depth. This approach is based on written legal provisions, namely statutory regulations specifically related to the protection of the law against human rights violations that befall Uighur Muslim ethnic women in China.

\section{Human Rights as Fundamental and Universal Rights}

The concept of Human Rights (HAM) includes three main elements for human existence as both an individual and a social being, namely human integrity, freedom and equality (Allan Rosas, 1995). The three elements are conceptualized into definitions and understandings of what human rights are.

The understanding of this definition becomes clear when recognition of these rights is given and is seen as a humanization process by other parties in a vertical (individual to state) and horizontal (between individuals) context, both de facto and de jure. Thus, human rights values are fundamental and universal with the recognition, protection and promotion of human integrity, freedom and equality in the main international human rights instruments, at the international, regional and national levels. Although the values are universal, human rights can be divided into several normative academic groupings, namely, first, personal rights or "personal rights". Second, economic rights or the right to own something ("property rights"). Third, the right to get equal and equal treatment in law and government or the "right of legal equality". Fourth, political rights or "political rights". Fifth, social and cultural rights or "social and cultural rights", such as obtaining and choosing education, develop a preferred culture. Sixth, the right to litigate and protect it or "procedural rights". The understanding and understanding of human rights in terms of substance becomes complex and complex based on developments, existing realities and the complexity of other determinants.

Human rights concepts and values change over time through both evolutionary and revolutionary processes from normative forces into processes of social and political change in the entire order of human life (Perwira, 2003). Thus, understanding and understanding of the meaning of human rights in terms of substance must be returned to the basic concept of why human rights exist. Human rights exist and arise because these human rights are very basic in nature in the sense that their implementation is absolutely necessary so that humans can develop according to their talents, aspirations, and dignity as human beings regardless of differences that cause discrimination based on nation, race, religion and gender. The 
principles of understanding human rights must be used as the main basis so that the understanding and understanding of human rights from a substantive perspective can be applied. These principles are the application of the concept of indivisibility and the interdependence of human rights values (UNICEF, 1998).

According to his ontology, human rights are rights owned by humans that are obtained and carried along with their birth or presence in society because they have a privilege that opens the possibility for them to be treated according to these privileges (Huijbers, 1990). In a simpler sense, human rights are the rights of a person, which if these rights are taken away from him will result in that person becoming no longer human (United Nations, 1998).

Human rights, as understood in human rights documents that emerged in the twentieth century such as the Universal Declaration of Human Rights (UDHR), has a number of prominent characteristics, namely (James W., 1987): First, so that we do not losing the clear idea, human rights are rights. The meaning of this term is not clear, but at least it shows that it is a definite and high priority norm for which enforcement is mandatory. Second, these rights are considered to be universal, which are owned by humans solely because they are human. This view implies that characteristics such as race, gender, religion, social position, and nationality are irrelevant to question whether a person has or does not have human rights. It also implies that these rights can be applied worldwide. One of the special characteristics of human rights currently in effect is that they are international rights. Adherence to such rights has been viewed as an object of legitimate international concern and action.

Third, human rights are considered to exist by themselves, and do not depend on their recognition and application in customary systems or legal systems in certain countries. This right may not be an effective right until it is exercised according to law, but it does exist as a standard of argument and criticism independent of the application of the law. Fourth, human rights are seen as important norms. Although not entirely absolute and without exception, human rights have a strong enough position as a normative consideration to be enforced in conflict with conflicting national norms, and to justify international action taken for the sake of human rights. The rights set out in the Declaration are not arranged according to priority; their relative weights are not specified. It is not stated that some of them are absolute.

Therefore, the human rights described in the Declaration are what philosophers call prima facie rights. Fifth, these rights imply obligations for both individuals and 
governments. The existence of this obligation, as well as the rights related to it, is deemed independent of its acceptance, recognition or application. Governments and persons everywhere are obliged not to violate a person's rights, although that person's government may at the same time have the primary responsibility to take positive steps to protect and enforce that person's rights. Sixth, these rights establish minimum standards for proper societal and state practice. Not all problems born of cruelty or selfishness and ignorance are human rights problems. For example, a government that fails to provide national parks for its people can be denounced as incompetent or not paying enough attention to opportunities for recreation, but that will never become a human rights issue.

The state and each individual have their own role in the implementation of human rights. The role of individuals is related to the principle of balance as stated above, namely that human rights do not only contain authority or freedom but also individual responsibilities or obligations, and every individual as a human rights subject has the obligation or responsibility to respect the human rights of others, as well as other people being demanded. to respect his human rights. Violation of one's human rights by another individual is an act that can be held accountable legally.

However, the role of the state is very central and important in the implementation of human rights. Referring to various human rights instruments, it is a state that has the obligation to ensure the fulfillment of human rights. The state has an obligation to ensure that human rights are respected, protected, promoted and fulfilled. Respect (to respect), protect (to protect), promote (to promote) and fulfill (to fullfill) shows the level of action or actions that must be taken by the state in relation to the implementation of human rights. Respect is the government's most "minimal" action (in the form of negative action, meaning not to commit violations), and fulfilling is the state's obligation to take the most "full" effort for the realization of human rights (Yuliartini, N. P. R, 2019).

The nature of state obligations mandated in international human rights instruments with regard to the implementation of human rights differs between civil and political rights, and economic, social and cultural rights. For civil and political rights, the ICCPR obliges the state to "immediately" take the necessary steps in the field of legislation or other steps in order to respect and ensure the implementation of these civil and political rights. As for economic, social and cultural rights, the ICESCR obliges the state to take steps, bearing in mind the maximum resources it has, in order to progressively realize these economic, social and cultural rights. 
This is understandable because the realization of civil and political rights does not require large economic resources as in economic, social and cultural rights. However, this does not mean that the state is only obliged to take measures in order to realize these economic, social and cultural rights when the state has reached a certain level of economic growth. Regardless of the capacity of the economic resources or other resources, a country should move as soon as possible towards the realization of these rights. In addition, there are several rights guaranteed in the ICESCR which do not require large economic resources. The state, for example, can immediately reform laws that are discriminatory in nature, or that cause people to be prevented from enjoying their rights, or laws and regulations that "facilitate" violations of rights by the state. Such steps do not have to wait until the country is truly prosperous (Mangku, 2013).

When a country ratifies an international human rights instrument, it can directly incorporate the provisions of that instrument into its domestic legislation and / or through other measures. Human rights implementation can be done as well as possible if there is good legislation, an independent judiciary, and established democratic institutions. In addition, education and dissemination of human rights values are very important efforts in the context of implementing human rights (Arianta, 2020).

\section{History of Ethnic Uighur Women}

The Uighurs are a minority ethnic group in the Xinjiang region, located on the western and northwestern tip of China. This tribe has its own province with an autonomous status called Xinjiang-Uighur. The majority of the Uighurs are Muslim. "Uighur" itself means unity or fellowship. Uighur Muslims speak the local language and are Turkmen. They wrote in Arabic. According to Anshari Thayib, in the book Islam in China published by Amarpress, the beginning of Islam's entry into Xinjiang was when the Uighur community acted as intermediaries for trade between China and the West. Historically, the Xinjiang region used to be known as "East Turkistan".

The area of East Turkistan alone reaches 1.6 million square kilometers or one-fifth of the area of China. Thanks to long interactions with Arab, Persian and Turkish traders, the Uighur community began to recognize and embrace Islam. The number of Uighur Muslims in 2011 was around 8 million. Meanwhile, the number of Muslims in China in 2011 was around 20 million out of China's total population of 1.3 billion. 
Since the Communist government's takeover of the Turkistan region in 1949, the number of communist Han Chinese in the region has increased from $6.7 \%$ to $40.6 \%$, according to official figures. They later emerged to control all major political functions and activities in the Xinjiang region. With the support of the Chinese government, they also enforce conditions that isolate and limit the performance of religious rituals, and prohibit Uighur Muslims from using their language in schools.

Starting from these discriminatory policies resulted in conflict between Uighur Muslims and the Chinese government as well as ethnic conflict between Uighur and Han tribes. The Chinese government's marginalization of Muslim Uighur women is due in part to the fact that the Xinjiang region has abundant natural resources. Before being colonized by the Chinese communist government, in the 1940s, the East Turkistan Republic had emerged in parts of Xinjiang which were considered part of their human right to independence.

However, the establishment of the East Turkistan Republic was not recognized by the Chinese communist government. China considers Xinjiang a part of its territory. Even Mao Zedong immediately sent troops to Xinjiang in 1949. At its peak, on October $1^{\text {st }}, 1955$, Xinjiang was officially made a province with the status of an autonomous region despite the fact that the majority of its population at that time was Uighur.

\section{Forms of Human Rights Violations Accepted by Ethnic Uighur Women}

Based on the report released by researcher Adrian Zenz, this has led to international calls for the United Nations to investigate the Chinese government regarding Uighur Muslim women, which is based on a report issued by Adrian Zenz that the Chinese government forces Uighur Muslim women in Xinjiang Province to put on contraceptives in an effort to limit the Muslim population. Uyghurs. However, the Chinese Government has issued a statement that what was conveyed is untrue and baseless

Zenz's report is based on a combination of official regional data, policy documents and interviews with ethnic minority women in Xinjiang. The report alleges that Uighur and other ethnic minority women were threatened with being held in camps for refusing to abort pregnancies that exceed the birth quota. He also said women who have fewer than two children - according to the law - have contraceptives placed in their wombs without the woman knowing it, while others 
are forced to accept sterilization surgery. Zenz's analysis of the data shows that natural population growth in Xinjiang has dropped dramatically in recent years, with growth rates in the two largest Uighur regions plunging 84\% between 2015 and 2018 and further decreasing in 2019.

Forced sterilization is a practice carried out to reduce or eliminate a person's reproductive ability without the person's consent. Over the years the Chinese Government has implemented a policy of forced sterilization against ethnic Uighur women, this policy was implemented with the aim of suppressing and reducing the population growth and birth rate of the Uighur ethnic community, as well as being a way to repress the Uighur ethnic community so as not to commit "separatist and terrorism behavior. ". However, this policy clearly violates the human rights of the Uighur ethnic community as stipulated in various existing international legal instruments.

\section{Legal Protection Against Human Rights Violations Befallen Uighur Muslim Ethnic Women in China}

Internationally, human rights are included in an international legal system established by the international community consisting of states (Mangku, 2012). The state has an important role in shaping such a legal system, namely through international customs, international agreements or other forms such as declarations or technical guidelines. Then the country declares its agreement and is bound by international law. Human rights provide protection which can be in the form of an individual, group or property. The state or state officials as part of the state have an obligation in the international sphere to protect citizens and their assets. International human rights standards are established and developed in various negotiations in international forums.

The process of establishing this standard is carried out by representatives from each country in an international forum which has gone through a long process with a long period of time. This formation process not only discusses the substance and form of a draft declaration and agreement to be agreed upon, but can be discussed in detail in articles, word-for-word proposals from the contents of the agreement can then be agreed to become an international agreement by countries. The UN Charter, committed to fulfilling, protecting human rights and respecting the basic human freedoms universally is emphasized repeatedly, including in article 1 number 3 
which states to promote international cooperation in solving international problems that occur, especially in the economic, social, cultural fields. , and humanity, and defeating and promoting respect for human rights and fundamental freedoms for all persons regardless of race, sex, language or religion. This commitment was then followed up by the United Nations through the formation of legal instruments that regulate human rights (Itasari, E. R. 2019).

The chronology of cases of human rights violations against ethnic Uighur women, in general, initially started with the Chinese government, which is a Communist country and ethnic Uighurs, which are the fourth largest ethnic group in East Turkistan and embracing Islam, of course cause particular concern for the Chinese government. Because, the Chinese government considers that the things that Uighur ethnic women adhere to and do can result in a cultural shift in China, especially in the Xinjiang area. So, to avoid things that China doesn't want, the Chinese government creates and builds special camps for ethnic Uighur women such as foundations or schools (Itasari, E. R. 2019).

With the aim that ethnic Uighur women do not deviate and with the aim of providing a nationalist understanding and thinking so that there is no cultural shift in the Xinjiang region. However, in the applications carried out by the Chinese government, there are actions that are considered unnatural and incompatible with humanity. The actions taken by the Chinese government by building places on the pretext of schools or foundations to teach the culture and nationalist spirit to ethnic Uighur women is an act that violates human rights and the actions taken are also a form of discrimination against one particular ethnicity, namely Uighur ethnic women.

About 1 million ethnic Uighurs reside in camps set up by the Chinese government. It is known, when one of the international media belonging to the United States, The New York Times, officially reported that what was happening inside the camps did not look like a place to study but rather a place to detain ethnic Uighurs or brainwashing. The New York Times reported that there was a document from China's leader, Xi Jinping, ordering officials to take action against separatism without mercy aimed at the ethnic Uighur minority group.

The document, which is approximately 403 pages thick, states that Xi Jinping provides directions to supervise, control, regulate and suppress the population of ethnic Uighur women. The Chinese government, commits human rights violations aimed at ethnic Uighur women in various actions and efforts by depriving Uyghur 
women of human rights, such as: prohibiting ethnic Uighur women from practicing religion or practicing worship properly. acts of violence, acts of discrimination, acts of slavery, acts of persecution and torture that injures physically and mentally, and acts of threatening even to the occurrence of acts of murder against ethnic Uighur women that have been committed by the Chinese government. So that these violations committed by China have usurped various basic rights that the Uighurs should have, namely: the right to life, the right to freedom of speech, the right to express the aims and objectives, the right to freely practice a religion that is and, the right to get a decent job and education, the right to associate with family, and other rights (Itasari, ER 2018).

The gross human rights violations committed by the government of Xinjiang, China against ethnic Uighur women constitute a crime against a group of human beings by discriminating against, forcibly detaining and expelling them and by systematically structured actions. Ethnic Uighur women in this caasus are not given freedom in carrying out their worship and religion. This happens during the months of Ramadan, when Uighurs should fast and pray. However, it is not permitted and to carry out these activities. If anyone tries or violates the things that have been determined, they will be arrested or punished and put in a recovery camp, which is actually a brainwashing camp so that the Uighur ethnic community does not live a religious life as it should be in accordance with their rights and freedoms. .

Ways or steps, to reduce and combat racial discrimination that has been made by the United Nations against an ethnicity, namely by adopting a number of resolutions as well as conventions and declarations. In the first world conference to eradicate racism and racial discrimination that exists and is occurring, countries are urged to immediately eliminate discrimination because of any background, whether in the form of ethnic or national differences among their citizens. The state is also guided to protect and promote human rights as well as for minority ethnic groups and national groups. The Conference which took place between these countries was recommended to immediately adopt special measures, especially in the fields of economic, social, educational, cultural and civil and political rights.

This is aimed at ensuring that all people around the world will enjoy such a thing as legal equality and harmony. So, this can be a guarantee that discrimination that occurs between the majority group and the minority group has been eliminated or minimized. International instruments that have regulated legal protection for ethnic Uighurs, whose ethnicity has experienced discrimination and treatment that 
is not in accordance with international human rights by the Xinjiang government in China. The governing conventions are: The Convention on the Prevention and Punishment of the Crime of Genocide was adopted through UN General Assembly Resolution 260 A (III) on 9 December 1948. This convention is in effect since 12 January 1951. then the Convention On The Prevention And Punishment Of The Crime Of Genocide is the first human rights treaty ratified by the general assembly of the United Nations. This Convention focuses attention on protecting national racial, ethnic and religious minorities from threats to their existence, especially in terms of discrimination.

Article 2 of the Convention on the Prevention and Punishment of the Crime of Genocide protects the existence of an ethnic group from all acts that may cause the partial or complete extinction of a particular ethnic group either by preventing the birth of a baby in that ethnic group or the loss of the life of a person belonging to the group. the. The perpetrator of the genocide crime, as well as the one who planned the crime of genocide, whether it is a constitutionally responsible leader, a public official, or an individual can be tried in a court in the State where the crime of genocide was committed or resolved through an international court having jurisdiction. The cases that occurred in Xinjiang related to human rights violations against ethnic Uighurs can be brought to trial because they have led to crimes of genocide. Therefore, the Chinese government has the right to be tried in relation to the problems that occurred in the country.

\section{Conclusion}

The legal protection provided for ethnic Uighur women, in this case the case that occurred in Kosovo, Yugoslavia, can be used as a reference for making rules or policies on equal rights between ethnic Uighurs and Chinese, establishing temporary courts as an effort to resolve, responsibility Protect from groups, communities or international organizations if the state is negligent in protecting its citizens from the crime of genocide. Forms of legal protection for ethnic Uighur women The UN Human Rights Council can also investigate problems that occur and form an international committee, and can take the form of implementing policies that have been regulated in international legal rules. Legal protection for ethnic Uighur women is also based on articles 3, 5, 9, 10 and 11, the Universal Declaration of Human Rights (DUHAM) is to provide protection to ethnic Uighurs in the form of the right to life, the right to freedom and personal security, the prohibition of torture. 
human dignity. Legal protection in the International Covenant on Civil and Political Rights of 1966 is the protection of the right to life, the right not to be tortured, treated or punished cruelly, the right to freedom, and the right to personal security. International Covenant on Economic, Social and Cultural Rights, Convention on Genocide, International Convention against Torture, International Convention on the Elimination of All Forms of Racial Discrimination 1965, Convention on the Elimination of All Forms of Discrimination Against Women and Convention on the Rights of the Child. International dispute resolution, related to gross human rights violations against ethnic Uighur women under article 33 of the UN Charter, the disputing parties (ethnic Uighur women and the Government of Xinjiang, China) can resolve problems that occur through peaceful settlement methods, using political channels using negotiations carried out between ethnic Uighur women and the Xinjiang Government as well as through mediation using a moderator as a third party to help problems that occur between the two parties. If this method is not yet relevant or successful, the UN Council can submit cases that occur to international courts such as the International Criminal Court (ICC) as regulated in article 1 of the 1998 Rome Statute.

\section{References}

Arianta, K., Mangku, D. G. S., \& Yuliartini, N. P. R. (2020). Perlindungan Hukum Bagi Kaum Etnis Rohingya Dalam Perspektif Hak Asasi Manusia Internasional. Jurnal Komunitas Yustisia, 1(1).

Eide, Asbjorn, Catarina Krause, Allan Rosas, 1995, Economic, Social and Cultural Rights, A Textbook, Martinus Nijhoff, Dordrecht.

Itasari, E. R. (2018). Implementasi Pemenuhan Hak Pendidikan Warga Negara Indonesia Di Perbatasan Darat Antara Indonesia Dan Malaysia. Jurnal Ilmiah Ilmu Sosial, 4(2).

Itasari, E. R. (2019). Fulfillment Of Education Rights In The Border Areas Of Indonesia And Malaysia. Ganesha Law Review, 1(1).

Itasari, E. R. (2019). Hak Untuk Pendidikan yang Diterima oleh Masyarakat Indonesia di Perbatasan Darat dalam Persepktif Hak Asasi Manusia. Majalah Ilmiah Cakrawala Hukum, 21(1).

Mangku, D. G. S. (2013). Kasus Pelanggaran Ham Etnis Rohingya: Dalam Perspektif ASEAN. Media Komunikasi FPIPS, hlm. 12(2). 
Mangku, D. G. S., \& Lasmawan, I. W. (2020). Perlindungan Hukum Terhadap Kaum Etnis Uighur Dalam Perspektif Hak Asasi Manusia Internasional. Jurnal Komunitas Yustisia, 3(1).

Nickel, James W., 1987, Making Sense of Human Rights: Philosophical Reflection on the Universal Declaration of the Human Rights, The Regents of the University of California.

Saragih, M. F., Hamid, S., \& Munthe, M. (2016). Tinjauan Yuridis Pelanggaran Ham Terhadap Muslim Uighur Di China Ditinjau Dari Hukum Humaniter. Sumatra Journal of International Law, 4(2).

Sujatmoko, Andrey. 2016. Hukum HAM Dan Hukum Humaniter. Jakarta: PT Raja Grafindo Persada.

Taihitu, Bonanza Perwira,2003, Penaatan Indonesia pada Standar-Standar HAM Internasional Dalam Kurun Waktu 1991-2002, Thesis pada Fakultas Ilmu Sosial dan Politik Departemen Ilmu Hubungan Internasional, Pasca Sarjana Universitas Indonesia.

Theo Huijbers, 1990, Filsafat Hukum, Penerbit Kanisius, Yogyakarta, hlm. 96.

Undang-undang Republik Indonesia Nomor 39 Tahun 1999 tentang Hak Asasi Manusia, Indonesia Legal Center Publishing, Jakarta, Mei 2010.

UNICEF, 1998, A Human Rights Approach to UNICEF Programming for Children and Women: What It is and Some Changes It Will Bring.

United Nations, 1998, Human Rights, Questions and Anwers, United Nations Department of Public Information, New York.

Yuliartini, N. P. R., \& Mangku, D. G. S. (2019). Tindakan Genosida terhadap Etnis Rohingya dalam Perspektif Hukum Pidana Internasional. Majalah Ilmiah Cakrawala Hukum, 21(1).

Mangku, D. G. S. (2012). Suatu Kajian Umum tentang Penyelesaian Sengketa Internasional Termasuk di Dalam Tubuh ASEAN. Perspektif, 17(3), 150-161. 
